\title{
Training of educational technicians specialized in activity-based learning at institutions of higher education
}

\author{
Vladimir Lvovskiy ${ }^{1 *}$, Anton Agapov ${ }^{1}$, and Tatiana Mysina ${ }^{1}$ \\ ${ }^{1}$ Moscow City University, Institute of System Projects, Moscow, Russia
}

\begin{abstract}
A teacher mastering a new paradigm needs professional support. In this case, it is recommended to create collective pedagogical action, in which all reflexive functions are performed by a teacher together with colleagues and educational technicians specialized in activity-based educational methods. The specific task of educational technicians is to follow semantic guidelines and normative frameworks of the abovementioned pedagogical action. The reflexive position of educational technicians in relation to teaching means is that they should rely on activity-based learning and the corresponding principles of organizing and managing educational processes while supporting teachers. Thus, it is necessary to state that activity-based learning with its foundations, objectives, and methods has not acquired a comprehensive form for its popularization among school teachers. Currently, this paradigm is represented by a set of theoretical constructs from classical Russian psychology and a description of different educational experiments. The prerequisites for the training of educational technicians are associated with the application of the activity-based approach, which is the most developed in general education, for the training of educational technicians specialized in activity-based learning at institutions of higher education, including through the organization of quasi-professional activities. The study aims at considering various aspects of training educational technicians at institutions of higher education, including the specifics of the interim assessment. The authors of the article examine the corresponding literature on activity-based formats of professional training, as well as methods of forming educational events and outlining their content. The results obtained in the course of the study offer possible solutions to creating favorable conditions for the experimental and productive actions of future educational technicians. The novelty of the study is determined by a new approach to the training of educational technicians, which includes educational games having both diagnostic and reflexive potential. Keywords: activity-based learning; competency-based education; professional training.
\end{abstract}

"Corresponding author: lvovskiyva@mgpu.ru 


\section{Introduction}

The existing federal educational standards are based on the Russian scientific schools founded by L.S. Vygotsky, S.L. Rubinstein, G.P. Shchedrovitsky, etc., as well as activitybased learning. The main problem of adopting activity-based educational standards is that most pedagogical community, including lecturers of higher education institutions and methodologists of different levels, is hardly familiar with both the origin of activity-based learning and the corresponding activity-based educational practices [1, 2]. Activity-based learning is a fundamentally open method of pedagogical action based on educational processes and creative psychological and pedagogical experimentation [3]. Attempts to technologize this process for the convenience of students and teachers lead to simplifications and distortions.

To overcome the difficulties associated with the restructuring of pedagogical activity towards the competency- and activity-based paradigm $[4,5]$, there is a need for collective pedagogical action [6] and a new position of a specialist accompanying the abovementioned transition, i.e. an educational technician specialized in activity-based learning.

The study aims at considering various aspects of training educational technicians at institutions of higher education, including their interim assessment.

The research tasks are as follows:

- To analyze activity-based educational methods from the perspective of scholars supporting the ideas of L.S. Vygotsky and other scientific schools of the $21^{\text {st }}$ century;

- To describe the activity model of educational technicians;

- To form a model of training educational technicians in the framework of Master's Degree courses.

\section{Methods}

To describe the training of educational technicians specialized in activity-based learning, we needed to study the relevant literature on the activity-based foundations of higher education. In the course of the study, we examined the scientific works of teachers and psychologists representing various directions of the activity-based approach both in general and professional education. Most of these sources (monographs and periodical articles) were published in the second half of the $20^{\text {th }}$ century. In addition, we analyzed texts that describe the training of pedagogical staff performing functions similar to those performed by educational technicians. Most of these texts were published as brochures and website descriptions of the respective projects in the period from the early 2000 s to 2020 . The next stage comprised methods of forming educational events and outlining their content. The resulting schemes laid the basis for reviewing the training of educational technicians at universities.

\section{Results}

Activity-based learning is based on L.S. Vygotsky's cultural and historical theory of human mental development $[7,8]$. His ideas laid the basis for three areas of psychology forming a theoretical framework for understanding the essence of activity-based learning [9], A.N. Leontiev's activity theory [10], D.B. Elkonin's concept of age periodization [11], and V.V. Davydov's theory of educational subjects [12]. Based on this theoretical framework, we developed a scheme for the activity of educational technicians that meets the provisions of the activity-based approach in relation to teachers [13]. The scheme is shown in Figure 1. 


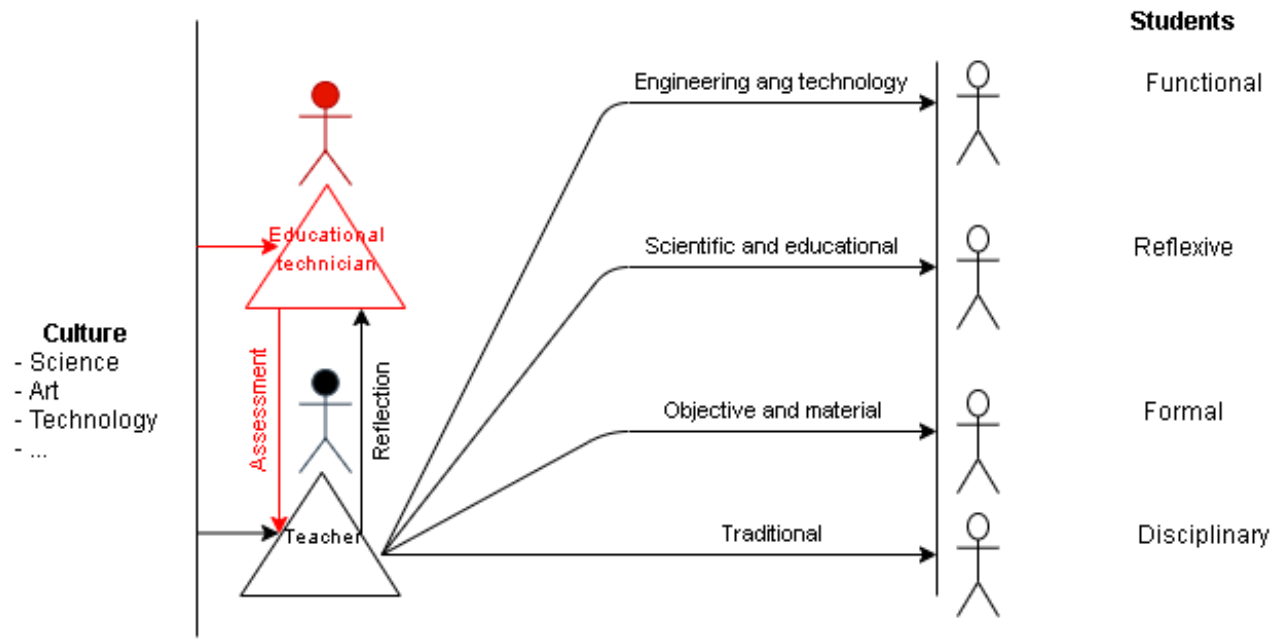

Fig. 1. The graphic scheme of the specialist's functioning.

On the left, the scheme represents the content for cultural transmission that should be passed on to future generations. This content, conventionally designated as "culture", includes science, art, technology, and other cultural and civilizational prototypes.

The triangles denote "prisms of consciousness", through which the content of culture, didactics, and methods is "refracted" and becomes a subjective means within the professional activity of teachers and educational technicians. Teachers utilize their professional consciousness as a means of initiating and organizing student actions in conformity with the above-mentioned prototypes. Moreover, the content of these actions and their limitations might not be obvious for teachers and can be turned into stereotyped and predictive algorithms of functioning [14].

On the right, the scheme depicts students who, being involved in one of the actions, become their subjects at the appropriate level they have mastered, in particular, disciplinary, formal, reflexive, or functional [15].

The competencies of educational technicians are directly related to their activity model. According to this model [16], educational technicians can play both diagnostic and forming roles. However, their actions in these two roles are fundamentally different and cannot overlap in time since these processes, if they take place simultaneously, do not allow the full implementation of these actions. It is stated that a certain stage of formation is finished and something that has shown its inadequacy during testing is revealed. These actions develop diagnostic and forming competencies of educational technicians.

Based on the above-mentioned activity model, it is necessary to organize the training process in such a way that there is polypositionalism in learning, the possibility to form and analyze the necessary competencies, including diagnostic ones, as well as to reflect and evaluate their development.

To accomplish this task, a special type of exam was introduced into the learning process [17]. Over time, the exam and exam preparation turned into a separate training course that included several in-term meetings and ended with an educational event during the examination session.

The exam fulfills the following objectives:

- To reflect on the content of the disciplines mastered during the term;

- To receive feedback from students on the construction and content of disciplines through the organized application of this content;

- To make Master's Degree students subject to the content of their education through exam preparations; 
- $\quad$ To do it actively and easily (with humor).

The first module "Theoretical and empirical research" introduces, forms, and develops concepts in the field of cultural-historical psychology and activity-based learning. An educational event within this module encourages graduate students to design and conduct a fragment of the lesson aimed at mastering one of the key concepts proposed by their teachers.

While preparing for the educational event of the second module "Design in education", graduate students develop an academic and methodological complex to reconsider the educational content of the existing courses. They also undertake some functions of designers of educational events while working with the concepts inherent in the academic and methodological complex.

The third module forms the diagnostic competency of educational technicians. The key difference between the third exam and the previous ones is that graduate students become full-fledged co-creators of the exam (Figure 2). During the term, they need "to develop diagnostic materials to check the competencies mastered at the previous stage (in conformity with the academic and methodological complex)". At the same time, the quality criteria for such diagnostic materials are developed together with graduate students.

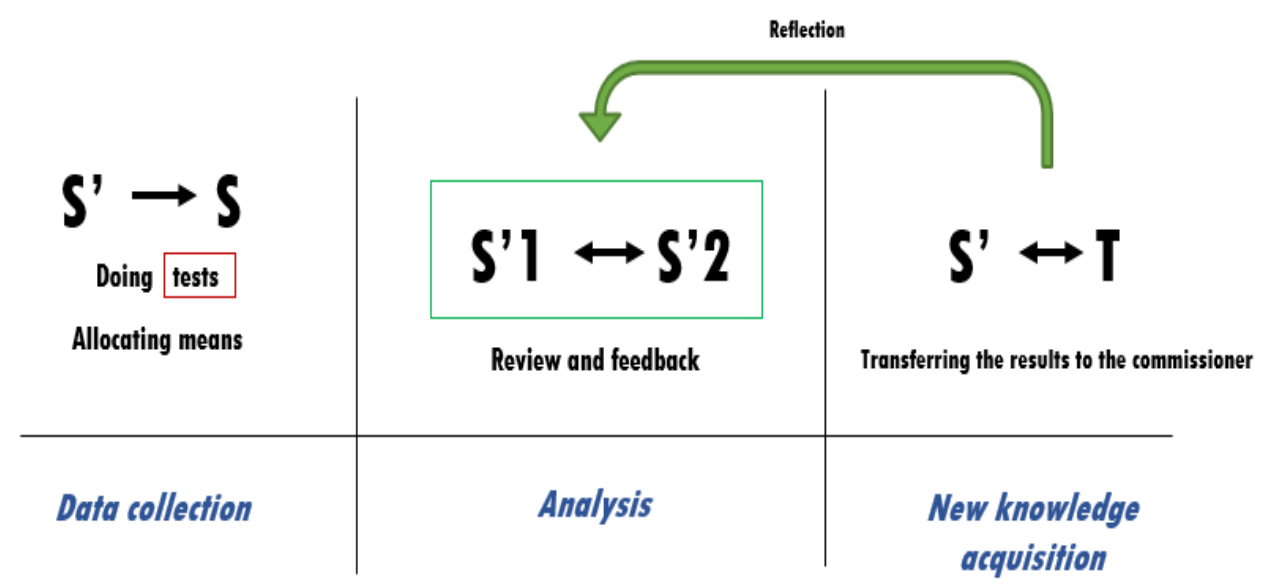

Fig. 2. The third module scheme of training educational technicians specialized in activity-based learning.

The educational event has a rather complex and multi-layered structure. It comprises the following actors:

- Second-year Master's Degree students of the specialty "Educational Technician Specialized in Activity-Based Learning" ( $\left.\mathrm{S}^{\prime}\right)$;

- Second-year Master's Degree students of the specialty "Design and Examination of Preschool Education (L.S. Vygotsky's cultural and historical approach)" (S');

- First-year Master's Degree students of the specialty "Design and Examination of Developmental Education" (S);

- Teachers (T).

Stage 1: freshmen do the tasks compiled by sophomores.

Stage 2: sophomores check the tasks and experts examine the diagnostic materials and evaluate them.

Stage 3: the results of diagnostics are forwarded to heads of Master's Degree courses, the validity and reliability of diagnostics are discussed, the authors receive feedback from freshmen and experts. 


\section{Discussion}

The effect of such training is constant feedback from graduate students, which makes lecturers reconsider the format of their courses in conformity with the activity-based approach and personalize the educational content. In addition, the constant activity of students helps them to look at their course through the eyes of practitioners and to restructure the content in such a way that it becomes more applicable.

Russia and foreign countries have similar experience in training instructional coaches who work with teachers and promote activity-based educational methods: the "Educational technician" competition held by the Skolkovo Foundation, the training of technicians by the Association Montessori International, etc. [18-20].

Thus, activity-based and other educational approaches are an effective tool for training teachers. They are not widely represented in education, therefore further research and instructional design in this field can be productive.

\section{Conclusion}

The article substantiates the need to introduce the position of educational technicians specialized in activity-based educational methods and describes their key competencies and the training of such specialists at institutions of higher education.

The described training format is difficult to implement in traditional Master's Degree programs that adhere to the knowledge-based approach and translation principles of teaching. The main difficulties are associated with the inexperience of graduate students in "resistance to material", the lack of teamwork in solving open-ended tasks, and ineffective decision-making in multi-layered and multi-position activities. Furthermore, this training format is difficult to implement if lecturers teaching Master's Degree courses are used to assess the learning results solely in comparison with disciplinary norms and are not willing to build cooperation with students within problem-based learning and work according to a flexible scenario.

The presented format of training educational technicians can be implemented in preparing future psychologists and pedagogues alongside the study of modules so that lecturers could assemble the content of disciplines and reflect on the learning results achieved in the framework of renewed courses.

This training format is of particular significance for Master's Degree courses which prepare students for professional activities at the stage of formation. Such a type of education ensures the joint development of problem points and presents the results of joint work between students and experts in the form of a final product. In case there are insufficient grounds for examination, the event-based form of holding an exam has the opportunity to become a resource for the development of not only students but also experts.

\section{References}

1. B.D. Elkonin, Produktivnoe deistvie. Znak. Proba [Productive action. Sign. Test], in Praktiki razvitiya: zamysly, tekhnologii, konteksty. The proceedings of the 25 th scientific conference, Institute of Developmental Psychology, 19-21 April 2018, Krasnoyarsk, Russia (2019)

2. B.D. Elkonin, V. Semenova, Cultural-historical psychology, 14(3), 93-100 (2018). https://doi.org/10.17759/chp.2018140309 
3. M. Garreta-Domingo, D. Hernández-Leo, P.B. Sloep, Education, Technology and Design: A Much Needed Interdisciplinary Collaboration, in Designing for the User Experience in Learning Systems (Springer, Cham, 2018)

4. A.G. Asmolov, Volga pedagogical search, 1(23), 13-19 (2018)

5. I.V. Zhulanova, A.M. Medvedev, Mir Nauki, 5(6) (2017). Accessed on: December 16, 2020. [Online]. Available: https://mir-nauki.com/PDF/45PSMN617.pdf

6. I. Eriksson, Designing Teaching-Learning Practices Using Activity Theory as Guiding Tool-Examples from Teacher-Researcher R\&D Projects, in A Nordic Perspective on the Cultural and the Activity in Theory and Practice, The Sixth Nordic Conference on Cultural and Activity Research, 12-14 June 2013, Kristianstad University, Sweden (2014)

7. L.S. Vygotsky, V.V. Davydov, Pedagogicheskaya psikhologiya [Educational psychology] (Pedagogika, Moscow, 1991)

8. M.J. Packer, M. Cole, Oxford Research Encyclopedia of Psychology (2020). https://doi.org/10.1093/acrefore/9780190236557.013.581

9. A.B. Vorontsov, E.V. Chudinova, Uchebnaya deyatelnost: vvedenie v sistemu D. B. Elkonina -V. V. Davidova [Learning activity: introduction to D. B. Elkonin's - V. V. Davidova's system] (Izdatel A. I. Rasskazov, Moscow, 2004)

10. A. Leontiev, Deyatelnost. Soznanie. Lichnost [Activity. Consciousness. Personality]. (Politizdat, Moscow, 1975)

11. D. Elkonin, Izbrannye psikhologicheskie trudy [Selected psychological works]. (Pedagogika, Moscow, 1989)

12. V.V. Davydov, Teoriya razvivayushchego obucheniya [The theory of developmental teaching] (INTOR, Moscow, 1996)

13. A.M. Medvedev, I.V. Zhulanova, Mir Nauki, 7(3) (2019). Accessed on: December 16, 2020. [Online]. Available: https://mir-nauki.com/02psmn319.html

14. C. Beauchamp, L. Thomas, Cambridge Journal of Education 39, 175-189 (2009). https://doi.org/10.1080/03057640902902252

15. P.G. Nezhnov, Test SAM (Student Achievement Monitoring) in the educational practice (Nekommercheskoe partnerstvo Avtorskii Klub, Moscow, 2018)

16. I.V. Zhulanova, V.S. Krupnik, Voprosy pedagogiki, 6(1), 113-120 (2020)

17. T.Y. Mysina, A.M. Agapov, “Deyatelnostnomu pedagogu deyatelnostnyi ekzamen!”. Novyi format otsenochnykh protsedur ["An active pedagogue deserves an activitybased exam!" A new format of evaluation procedures], in Sbornik materialov II siezda trenerov-tekhnologov deyatelnostnykh obrazovatelnykh praktik, 5-6 July 2019, Belokurikha, Altai region, Russia (2020)

18. Fond Skolkovo, Konkurs "Obrazovatelnyi tekhnolog" [Competition "Educational technologist"] (2019). Accessed on: December 16, 2020. [Online]. Available: https://old.sk.ru/academy/p/edutech.aspx\#caption

19. Association Montessori Internationale, Montessori International Technician Training (n.d.) Accessed on: December 16, 2020. [Online]. Available: https://montessoriami.org

20. I.M. Osmolovskaya, E.O. Ivanova, M.V. Klarin, V.V. Serikov, Y.B. Aliev, Innovative educational practices: classification, design, modeling, in Conference EEIA 2019. International Conference "Education Environment for the Information Age", September 2019, Moscow, Russia (2019). https://doi.org/10.15405/epsbs.2019.09.02.68 